\title{
Corrective Feedback Provision: Mixed Pattern vs. Separate Pattern
}

\author{
Mansoor Fahim \\ Islamic Azd University, Science and Research Branch, Tehran, Iran \\ Email:dr.mfahim@yahoo.com \\ Hossein Hashemnezhad \\ Islamic Azad University, Science and Research Branch, Tehran, Iran \\ Email: h_hashemnezhad2000@yahoo.com
}

\begin{abstract}
One of the suggestions that advocates of process writing approaches to second language writing pedagogy have made is that teachers should attend to content in preliminary drafts before switiching to focus on form on later drafts. Although the reasons advanced for separating form-content-focused feedback onto different drafts seem sensible enough, some criticized this separation on several counts. Building on the implications of these suggestions, the present article investigated whether the mixed pattern is superior to separate pattern of content first then form feedback? The research sample was divided into two major groups of 40. The first group received direct written teacher commentary on content in the first draft and indirect CF on form in the second draft and the students in the second group received mixed pattern of direct written teacher commentary on content and indirect teacher written corrective feedback on form in the first draft and mixed pattern of direct oral commentary and indirect oral corrective feedback in the second draft of the second group. The findings revealed that there is not any superiority of mixed pattern of written/oral CF over separate patten of WCF. Finally implications were drawn for teachers and L2 writing instruction.
\end{abstract}

Index Terms - process writing, separate patten, mixed pattern, WCF, OCF

\section{INTRODUCTION}

Corrective feedback as directly related to productive skills, especially writing, is the most frequently cited type of feedback in the literature. The term negative feedback, negative evidence and corrective feedback are usually used interchangeably in SLA literature to refer to any indications of learners' non-target like use of the target language (Gass, 1997 cited in Kim, 2004). Ellis, Loewen and Erlam (2006) draw our attention to the fact that corrective feedback differs in terms of how implicit or explicit it is. In the case of implicit feedback, there is no overt indicator that an error has been committed, whereas in explicit feedback types, there is. Chaudron $(1988$, p.141) posits that corrective feedback may be message-focused or code-focused; it may be self- or other- initiated; corrective feedback may occur implicitly in the form of comprehension and confirmation checks, recasting and the like, or explicitly in the form of provision of the correct form by teacher, peer, or native interlocutor; it may be accompanied by an explanation, especially in the classroom setting. He further mentions that in the classroom setting more attention is apparently given to discourse and content errors than to either lexical, grammatical, or morphological errors.

As Ellis (1994) points out, the role of corrective feedback in language acquisition has been extensively debated. There has been a considerable body of research into the nature of teacher's correction in language classrooms. However, there have been few studies that have investigated what effect if any; formal corrections have on language acquisition.

The mater of how to correct errors is very much complex. Research on error correction methods is not at all conclusive about the most effective method or technique for error correction. It seems quite clear that students in the classroom generally want and expect errors to be corrected (Cathcart \& Olsen, 1976 cited in Brown 2000). Brown (2000 cites Baily, 1985) who suggested taxonomy of error treatment options in second language classrooms. There are 7 options in the taxonomy. The basic options are: 1 to treat or to ignore, 2. to treat immediately or to delay, 3. to transfer treatment to other learners or not, 4 . to transfer to another individual, a subgroup or the whole class, 5. to return or not to the original error maker after treatment, 6 . to permit other learners to decide to initiate treatment, 7 . to test for the efficiency of the treatment. Brown (2000) argues that all of the basic options are viable modes of correction in the classroom. The teacher needs to develop intuition through experience and solid eclectic theoretical foundations for ascertaining which option or combination of options is appropriate at a given moment.

\section{THEORETICAL FRAMEWORK}

Error correction has been one of the key issues in second language writing faced by both teachers and researchers. There has been controversy as to whether error feedback helps L2 students to improve the accuracy and overall quality of their writing (Truscott, 1999; Ferris, 1999). Truscott $(1999 ; 2007)$ held a strong view against error correction. He 
argued that all forms of error correction of L2 student writing are not only ineffective but also harmful and should be abandoned. He further emphasized that although most L2 students clearly desire grammar correction, teachers should not give it to them. Ferris (1999) rebutted this claim by arguing that Truscott had overlooked some positive research evidence on the effects of grammar correction. With the existing data (Hyland, 2003; Bitchener, 2008), it is still too early to have a conclusive answer to the question of whether error correction is effective in improving the accuracy of L2 writing in the long term for learners of all levels. Therefore, L2 writing teachers simply cannot dismiss students' strong desire for error feedback.

\section{A. First WHY. Why Content First Then Form? (Separate Pattern)}

According to Ashwell (2000), advocates of a process writing approach to second language writing pedagogy have made various suggestions about the best ways teachers can respond to their students' writing. One of these suggestions is that teachers should attend to content in preliminary drafts before switching to focus on form on later drafts. The supposition is that by doing so the teacher can encourage revision (making large-scale changes to content) on early drafts before helping the student with editing (making small-scale changes to form) on the final draft. One assumption is perhaps that focusing on form too early in the writing process can dissuade students from revising their texts. Another assumption is that giving advice that is intended to encourage revision too late in the process requires students to take risks when there is no chance for redress. It is also assumed that revision and editing need to be dealt with separately. It is still unclear, however, whether the content-then-form pattern of teacher response is in fact more effective than other patterns. The researcher in the first group separated content and form and gave much attention to content in the early drafts.

\section{B. Second WHY. Why Mixed Pattern of CF on both Content and Form in the Same Draft? (Why Avoiding Content and Form Separation?}

Although the reasons advanced for separating form- and content-focused feedback onto different drafts seem sensible enough, Ferris (2003) criticized this separation on several counts. First, there is no empirical evidence to support the assertion that simultaneous attention to content and form inhibits students from working on both during revision. On the contrary, in several studies in which teachers gave global and local feedback on the same text, L2 students showed the ability to improve their texts in both content and form during revision (Ashwell, 2000; Ferris, 1997). A possible explanation for this divergence from L1 composition research is that L2 student writers are well aware that they have linguistic deficits and make errors as they write, but they also know that improving their ideas is important as well (Ferris, 1995; Hedgcock \& Lefkowitz, 1994, both cited in Ferris, 2003). Thus they are motivated to address any and all writing problems as attention is called to them.

Second, as Ferris and Hedgcock (2005) state, the distinction between content and form may well be a false dichotomy, as content determines form, at least to some extent, and faulty form can obscure meaning for a reader. Such issues could properly be considered rather as a continuum, and rigid and somewhat arbitrary prescriptions about the types of comments teachers should give to their students at various stages of the writing process may well be inappropriate and unhelpful. Third, teacher feedback should be constructed according to the most critical needs of individual student writers (Ferris et al., 1997; Conrad \& Goldstein, 1999). If a student writes a first draft that is exemplary as to ideas, development, and organization, but that is crying out for careful editing, it would seem foolish for the teacher to turn himself or herself inside out trying to find constructive content-based comments to give to the writer merely because it is the first draft and attention to form is judged premature. Or, at the opposite extreme, a student's first draft may be so riddled with language problems that the teacher cannot possibly provide useful (or even accurate) meaning- based commentary until he or she has more clarity about what the student is trying to say (which may well be achievable only through a face-to-face conference, as discussed later in this chapter). In contrast, as any experienced writing instructor knows, a student may still be very much in need of content-focused response even on a penultimate essay draft. To ignore this need because it is "time" to focus only on grammar again seems counterproductive.

A final argument against waiting until the end of the writing cycle to give language- related feedback is that L2 student writers have a tremendous need for expert feedback on their written errors. Students in many contexts will fail their writing courses or university writing proficiency examinations solely because of language errors. The linguistic deficits that many bring to the writing class are real and substantial (Silva, 1993; Leki, 1990, both cited in Ferris, 2003) and it is critical that their instructors address them. Choosing to only give form-focused feedback on a few drafts throughout a writing course could be argued to deprive students of critically needed input on an issue that could ultimately make or break them.

\section{PURPOSE OF THE STUDY}

The purpose of the present study was to carry out a study to compare the effects of mixed pattern versus separate pattern of feedback provision. To test the research hypotheses, the students from separate group received written content feedback on their first drafts and written form feedback on their second drafts. The students from the mixed pattern group applied the mixed pattern of written content and form feedback on their first drafts and oral feedback on 
content and form in the second drafts. Given such theoretical underpinnings, this study sought to explore the following research question.

Are there any significant differences between the results of separate pattern and mixed pattern of CF provision?

$$
\text { IV. METHOD }
$$

\section{A. Research Setting and Participants}

Participants for experimental study comprised 80 EFL students who were nonrandomly selected from 140 EFL students of Islamic Azad University. The students had similar educational backgrounds in that they had been exposed to Basic Writing as prerequisite to Writing Course (I). They were all TEFL students taking Writing Course (I) at Islamic Azad University. They had a two-hour writing English class every week. Both groups received treatment during the whole semester, sixteen sessions, and their language development was tested both at the end and during the semester.

\section{B. Collection and Analysis of Data}

The sample was divided into two major groups of writing class I and II. Each major group included 40 participants and each one was exposed to experimental treatment as follows:

Class One: Received written corrective feedback (WCF)

Draft 1: Direct written teacher commentary on content

Draft 2: Indirect written corrective feedback on form

Class Two: Received both written and oral corrective feedback (WCF \& OCF)

Draft 1: Mixed written direct teacher commentary on content and indirect CF on form

Draft 2: Mixed oral direct teacher commentary on content and indirect CF on form

In this stage, the researchers operationalized the treatment conditions of the study within two major groups (Group I and Group II). A related aspect of this study was to compare the separate pattern of written content feedback followed by written form feedback in Group I with mixed written content and form feedback followed by mixed oral content and form feedback in Group II.

In each Group, the students were required to write four revised paragraphs of descriptive, narrative, opinion, and comparison and contrast genre with two drafts for each $(4 \times 2=8)$. The number of exchanges between teacher and students, both written and oral, was as follows:

Group I

$40=$ the number of students

$8=$ the number of written feedback for each student

$320=$ total number of exchanges between students and teacher in the form of WCF.

Group II

$40=$ the number of students

$8=$ the number of written or oral feedback for each student

$320=$ total number of exchanges between students and teacher in the form of WCF or OCF.

\section{RESULTS}

The purpose of this section is to demonstrate the degree of significance for the acceptance or rejection of the research question formulated at the beginning of the study. The data analyzed for experimental stage were based on both descriptive and inferential statistics. The findings from the experimental stage are presented by the fillowing hypothesis.

Research Hypothsis: Priority of Mixed Pattern over Separate Pattern of CF Provision

Advocates of mixed pattern state that the distinction between content and form may well be a false dichotomy, as content determines form at least to some extent, and faulty form can obscure meaning for a reader. Such issues could properly be considered rather as a continuum, and rigid and somewhat arbitrary prescriptions about the types of comments teachers should give to their students at various stages of the writing process may well be inappropriate and unhelpful.

Table 1 shows comparison between group 1 and 2 in terms of draft 1 , draft 2, post test 1 , and post test 2 . The result of chi-square indicated that, there are not significant differences between total number of feedbacks in group 1 and 2 in terms of post test 2 , post test 1 , and drafts $1 \& 2$ respectively $(\mathrm{P}=1.000>.05)$. 
TABLE 1

COMPARISON BETWEEN GROUP I AND II

\begin{tabular}{|c|c|c|c|c|c|}
\hline & Group I & & & Group II & \\
\hline \multirow{3}{*}{ Draft 1} & Content & 1804 & \multirow{3}{*}{ Draft 1} & Content & 1345 \\
\hline & Form & 0 & & Form & 3068 \\
\hline & Total & 1804 & & Total & 4413 \\
\hline \multirow{6}{*}{ Draft 2} & Content & 0 & \multirow{3}{*}{ Draft 2} & Content & 393 \\
\hline & Form & 3823 & & Form & 845 \\
\hline & Total & 3823 & & Total & 1238 \\
\hline & Total No. of & 5627 & & Total No. of & 5651 \\
\hline & Feedback in & & & Feedback in Group & \\
\hline & Group 1 & & & 2 & \\
\hline \multirow[t]{3}{*}{ Post 1} & Content & 80 & \multirow[t]{3}{*}{ Post 1} & Content & 64 \\
\hline & Form & 200 & & Form & 200 \\
\hline & Total & 280 & & Total & 245 \\
\hline \multirow{2}{*}{ Post 2} & Content & 80 & \multirow[t]{3}{*}{ Post 2} & Content & 56 \\
\hline & Form & 160 & & Form & 169 \\
\hline Total & & 240 & & Total & 225 \\
\hline
\end{tabular}

\section{CONCLUSION AND PEDAGOGICAL IMPLICATIONS}

As table 2 illustrates, in terms of 5 areas of content in both Groups I and II, the researchers' feedback follow a rational order. That is, the highly provided feedbacks are "ability to communicate" and "purpose of paragraph" and the least emphasized one is "supportive ideas". In terms of 3 areas of form, Group I is similar to Group II (Draft one: written CF) but they are different from oral CF (draft 2 and draft 3). Written CF on form follows "Grammar", "vocabulary", and "mechanics", while in oral corrective feedback; the order is "grammar", "vocabulary", and "mechanics". This indicates that teachers are not potential enough to provide oral CF in mechanical areas of form.

The result of this study uncovered the following:

1. There are not significant differences between total number of feedbacks in group 1 and 2 in terms of post test 2 , post test 1 , and drafts $1 \& 2$ respectively

2. Regarding the differences between Group I and II, as Table 2 shows, although the numbers of feedback in both drafts in terms of content and form are completely different, the total number of feedbacks is approximately the same

TABLE 2

DIFFERENT AREAS OF CONTENT AND FORM IN GROUP I AND II

\begin{tabular}{|c|c|c|c|c|c|c|}
\hline Content areas & $\begin{array}{l}\text { Group1/Draft } \\
1 \\
\text { WCF on } \\
\text { Content }\end{array}$ & $\begin{array}{l}\text { Group1/Draft } 2 \\
\text { WCF on Form }\end{array}$ & $\begin{array}{l}\text { Group 1/Draft } 3 \\
\text { Sustained errors } \\
\text { Content \& form }\end{array}$ & $\begin{array}{l}\text { Group 2/Draft } 1 \\
\text { Mixed WCF on } \\
\text { content and } \\
\text { form }\end{array}$ & $\begin{array}{l}\text { Group 2/Draft } 2 \\
\text { Mixed OCF on } \\
\text { content \& form }\end{array}$ & $\begin{array}{l}\text { Sustained errors } \\
\text { Content \& form } \\
\text { Group 2/Draft } 3\end{array}$ \\
\hline $\begin{array}{l}\text { Ability to } \\
\text { communicate }\end{array}$ & 452 & & 73 & 347 & 107 & 51 \\
\hline $\begin{array}{l}\text { Purpose of } \\
\text { paragraph }\end{array}$ & 401 & & 61 & 322 & 97 & 41 \\
\hline $\begin{array}{l}\text { Smooth } \\
\text { ideas }\end{array}$ & 378 & & 41 & 232 & 67 & 28 \\
\hline $\begin{array}{l}\text { Logical } \\
\text { organization }\end{array}$ & 319 & & 55 & 277 & 77 & 35 \\
\hline \multicolumn{7}{|l|}{ Supportive ideas } \\
\hline & 254 & & 27 & 167 & 45 & 23 \\
\hline
\end{tabular}

Form areas

\begin{tabular}{lccccc} 
Grammar & 1812 & 220 & 1389 & 578 & 330 \\
Vocabulary & 374 & 95 & 352 & 57 & 215 \\
Mechanics & 1627 & 191 & 1327 & 52 & 35 \\
\hline
\end{tabular}




\section{A. Implications for Teachers}

Reform of education is not simply reform of school system but reform of the behavior and thinking of the wider social teaching-learning process that guides moral-political ideas and behavior. Far-reaching curriculum innovation involves fundamental shifts in the values and beliefs of the individuals concerned (Burns, 1996).

Decisions related to EFL writing will affect teachers and EFL writing instruction. Teachers should feel confident about providing direct teacher commentary on content and indirect CF on form. For L2 writer, teacher's indirectness, especially when provided on content may add another layer of difficulty. In order to avoid the mentioned shortcomings, the researcher used direct metalingistic CF in the form of marginal and end direct commentary.Form has three clear divisions of grammar, vocabulary, and mechanics. Each of them is further subdivided into different clear-cut divisions such as prepositions, tense, agreement, spelling, etc. The clarity of form allows the corrector to provide indirect CF which requires the student to engage in "guided problem-solving" (Laland, 1982, cited in Ferris, 2003, p. 51)

Teachers should apply indirect codeded CF. On the practical level, it is much easier, faster, and more accurate for teachers to simply mark an error by highlighting, circling, or underlining it than to decide what error type it is and attach the appropriate code or verbal signal. On the other hand, it could be argued that coded feedback is more helpful to students than simple error location because it helps them to access metalinguistic information they may have learned (e.g., about verb tense rules or subject-verb agreement), giving them more tools with which to solve problems.

EFL teachers should use Mixed Pattern of CF on both Content and Form in the same draft. As Ferris and Hedgcock, (2005,) state and as the findings of this study show, the distinction between "content" and "form" may well be a false dichotomy, as content determines form, at least to some extent, and faulty form can obscure meaning for a reader. Such issues could properly be considered rather as a continuum, and rigid and somewhat arbitrary prescriptions about the types of comments teachers should give to their students at various stages of the writing process may well be inappropriate and unhelpful.

\section{B. Implications for L2 Writing Instruction}

EFL students are often anxious about writing and need to be encouraged to see it as a means of learning, rather than demonstrating learning. Instead of considering writing as a goal of language instruction, it would be better to focus on it as a means of developing language competence in such a way that the emphasis shifts from learning to write and moves in the direction of writing to learn. Teacher-students interactions through feedback is a kind of collaborative group work that may lead to greater opportunities for students to negotiate meaning as they work with peers in improving a written text. In pedagogical practice, viewing writing as a process-oriented activity encourages students to engage in multiple drafting and consider writing as occurring in stages that may differ to some extent among different writes.

\section{REFERENCES}

[1] Ashwell, T. (2000). Patterns of teacher-response to student writing in a multiple-draf composition classroom: Is content feedback followed by form feedback the best method? Journal of Second Language Writing, 9(3), 227-257.

[2] Bitchener, J. (2008). Evidence in support of written corrective feedback. Journal of Second Language Writing, 17(2), 102-118.

[3] Brown, D.H. (2000). Principles of language learning and teaching (4th ed.).New York: Addison Wesley Longman.

[4] Burns, A. (1996). Collaborative research and curriculum change in the Australian migrant English program. TESOL Quarterly, $30(3), 591-598$.

[5] Chaudron, C. (1988). Second language classrooms. Cambridge: Cambridge University Press.

[6] Conrad, S. M., \& Goldstein, L. M. (1999). ESL student revision after teacher-written comments: Text, contexts, and individuals. Journal of Second Language Writing, 8, 147-180.

[7] Ellis, R. (1994). The study of second language acquisition. Oxford: Oxford University Press.

[8] Ellis, R., Loewen, Sh., \& Erlam, R. (2006). Implicit and explicit corrective feedback and the acquisition of L2 grammar. Studies in Second Language Learning, 28 (2), 339-68.

[9] Ferris, D. R. (1997). The influence of teacher commentary on student revision. TESOL Quarterly, 31, 315-339.

[10] Ferris, D. R., Pezone, S., Tade, C. R., \& Tinti, S. (1997). Teacher commentary on student writing: Descriptions and implications. Journal of Second Language Writing, 6, 155-182.

[11] Ferris, D. R. (1999). The Case for Grammar Correction in L2 Writing Classes: A Response to Truscott (1996). Journal of Second Language Writing, 8(1), 1-11.

[12] Ferris, D. R. (2003). Response to student writing: Implications for second-language student. London: LEA Publishers.

[13] Ferris, D. R. \& Hedgcock, J. S. (2005). Teaching ESL composition: Purpose, process, and practice (2 ${ }^{\text {nd }}$ ed.). London: LEA Publishers.

[14] Hyland, F. (2003). Focusing on Form: Student Engagement with Teacher Feedback. System, 31(2), 217-230.

[15] Kim, J.H. (2004). Issues of corrective feedback in second language acquisition. Working Papers in TESOL \& Applied Linguistics, 4 (2), 1-24.

[16] Truscott, J. (1999). The Case for "The Case against grammar correction in L2 writing Classes": A response to Ferris. Journal of Second Language Writing, 8(2), 111-122.

[17] Truscott, J. (2007). The effect of error correction on learner's ability to write accurately. Journal of Second Language Writing, $16,255-272$. 
Mansoor Fahim was a member of the faculty of English Language and Literature at Allameh Tabataba'i University in Tehran, Iran from 1981 to 2008 when he was retired as an associate professor of TEFL. He has taught English at a welter of universities. At present, he runs Research methods, Psycholinguistics, Applied Linguistics, Second Language Acquisition, and Seminar classes at M.A.level and First Language Acquisition, Psycholinguistics, and Discourse Analysis courses at Ph.D. level at a number of universities including Allameh Tabataba'i and Islamic Azad Universities. Moreover, he has several published articles and books mostly in the field of TEFL and has translated some books into Farsi. Dr. Fahim is currently a member of the editorial board of some Iranian journals of Applied Linguistic Studies.

Hossein Hashemnezhad is a Ph.D candidate of TEFL at the Islamic Azad University, Science and Research Branch, Tehran, Iran. He has recently completed his Ph.D studies in the Islamic Azad University, Science and Research Branch. He is a lecturer at the Islamic Azad University, Khoy Branch and currently he is the Dean of the College of Humanities in the Islamic Azad University, Khoy Branch. His research interests are mainly focused on language teaching as well as assessment. He has published and presented papers in national and international conferences and journals. 